\title{
Pulsed laser deposition from ZnS and Cu2SnS3 multicomponent targets
}

Ettlinger, Rebecca Bolt; Cazzaniga, Andrea Carlo; Canulescu, Stela; Pryds, Nini; Schou, Jørgen

Published in:

Applied Surface Science

Link to article, DOI:

10.1016/j.apsusc.2014.12.165

Publication date:

2015

Document Version

Peer reviewed version

Link back to DTU Orbit

Citation (APA):

Ettlinger, R. B., Cazzaniga, A. C., Canulescu, S., Pryds, N., \& Schou, J. (2015). Pulsed laser deposition from $\mathrm{ZnS}$ and $\mathrm{Cu}_{2} \mathrm{SnS}_{3}$ multicomponent targets. Applied Surface Science, 336, 385-390.

https://doi.org/10.P016/j.apsusc.2014.12.165

\section{General rights}

Copyright and moral rights for the publications made accessible in the public portal are retained by the authors and/or other copyright owners and it is a condition of accessing publications that users recognise and abide by the legal requirements associated with these rights.

- Users may download and print one copy of any publication from the public portal for the purpose of private study or research.

- You may not further distribute the material or use it for any profit-making activity or commercial gain

- You may freely distribute the URL identifying the publication in the public portal

If you believe that this document breaches copyright please contact us providing details, and we will remove access to the work immediately and investigate your claim. 
Applied Surface Science: Special issue for the EMRS Spring Meeting 2014, Symposium J

SI:EMRS 14 Symp J: Laser-Mat

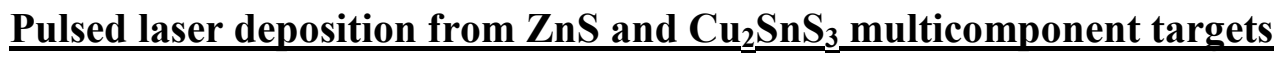

Rebecca Bolt Ettlinger ${ }^{1} *$, Andrea Cazzaniga ${ }^{1}$, Stela Canulescu ${ }^{1}$, Nini Pryds ${ }^{2}$ and Jørgen Schou ${ }^{1}$

${ }^{1}$ Department of Photonics Engineering, Technical University of Denmark, DK-4000 Roskilde

${ }^{2}$ Department of Energy Conversion and Storage, Technical University of Denmark, DK-4000 Roskilde

*reet@,fotonik.dtu.dk, +45 4677 4587, Department of Photonics Engineering, Frederiksborgvej 399, DK-4000 Roskilde, Denmark

\begin{abstract}
Thin films of $\mathrm{ZnS}$ and $\mathrm{Cu}_{2} \mathrm{SnS}_{3}$ have been produced by pulsed laser deposition (PLD), the latter for the first time. The effect of fluence and deposition temperature on the structure and the transmission spectrum as well as the deposition rate has been investigated, as has the stoichiometry of the films transferred from target to substrate. Elemental analysis by energy dispersive X-ray spectroscopy indicates lower $\mathrm{S}$ and $\mathrm{Sn}$ content in $\mathrm{Cu}_{2} \mathrm{SnS}_{3}$ films produced at higher fluence, whereas this trend is not seen in $\mathrm{ZnS}$. The deposition rate of the compound materials measured in atoms per pulse is considerably larger than that of the individual metals, $\mathrm{Zn}, \mathrm{Cu}$, and $\mathrm{Sn}$.
\end{abstract}

\section{Keywords:}

PLD; pulsed laser deposition; zinc sulfide; copper tin sulfide; $\mathrm{ZnS}$; $\mathrm{Cu}_{2} \mathrm{SnS}_{3}$ 


\section{Introduction}

Pulsed laser deposition (PLD) is a film deposition technique which is well suited for stoichiometric deposition of multicomponent materials $[1,2]$. PLD has the advantage that the atoms/molecules arriving at the substrate during deposition have a kinetic energy which may exceed the thermal energy with several orders of magnitude [3]. It is therefore possible to grow films which otherwise would require a much higher substrate temperature, and which grow under strong non-equilibrium conditions. Even for compounds with volatile elements the thin films usually exhibit optical, electronic and structural properties similar to the bulk [4-7]. However, for some materials with volatile components such as oxygen or sulfur, a part of the volatile fraction may be lost during the transfer to the substrate or during the film growth [2,8], which, for example, for oxides may lead to "metallic" rather than oxide films [9]. Therefore, in the case of oxides, a background gas is frequently used to ensure correct stoichiometry or structure of the growing film [8].

However, the procedure of compensating the loss of a volatile element with a background gas is undesirable with sulfur-containing compounds such as chalcogenides, as the gas $\mathrm{H}_{2} \mathrm{~S}$ is toxic and therefore difficult to handle. Though some researchers have used $\mathrm{H}_{2} \mathrm{~S}$ as background gas for PLD of $\mathrm{ZnS}$ [10], other groups have succeeded in using PLD with no background gas or with Ar to make chalcogenide thin films without significant S deficiency or loss of crystallinity, e.g., ZnS, AsS and GeS $[5-7,11]$.

We have previously used PLD to deposit the solar cell absorber material $\mathrm{Cu}_{2} \mathrm{ZnSnS}_{4}(\mathrm{CZTS})$ in vacuum with no background gas, and we have observed sulfur as well as tin losses at deposition temperatures above $350^{\circ} \mathrm{C}$ [12]. We here deposit $\mathrm{ZnS}$ and $\mathrm{Cu}_{2} \mathrm{SnS}_{3}$ at temperatures below $350^{\circ} \mathrm{C}$ in a similar single step process with ablation of a multicomponent target made from stoichiometric chalcogenide powders. Our measurements of CZTS films deposited on fused silica demonstrate that many phases occur [12] in contrast to films deposited on typical solar cell substrates such as Mo-coated soda lime glass.

$\mathrm{ZnS}$ and $\mathrm{Cu}_{2} \mathrm{SnS}_{3}$ are interesting materials, not only because they are multicomponent materials with the relatively volatile element sulfur, but also because they are secondary phases in the promising solar cell material CZTS which has a band gap of $1.45 \mathrm{eV}$ [13]. The additional grain boundaries from the secondary phases may trap the charge carriers in the solar cell absorber or directly lead to non-active 
"dark space" in the case of $\mathrm{ZnS}$ with a high band gap of more than $3.5 \mathrm{eV}$ [13]. These two effects are limiting the efficiency of the CZTS cell $[13,14]$. In addition, the cubic phases of $\mathrm{ZnS}$ and $\mathrm{Cu}_{2} \mathrm{SnS}_{3}$ are particularly hard to detect using X-ray diffraction within $\mathrm{Cu}_{2} \mathrm{ZnSnS}_{4}$, as the scattering peaks of all three compounds overlap [15]. Another interesting feature is that a pure absorber of $\mathrm{Cu}_{2} \mathrm{SnS}_{3}$ can be used as a solar cell absorber, albeit with a low efficiency [16].

$\mathrm{ZnS}$ is widely used in optical applications. It is a stable material transparent to infrared light, and in crystalline form it displays photo-, cathode- and electroluminescence when doped, e.g., with Mn [5,11]. In its cubic (zincblende) structure it has a direct band gap at about $3.54 \mathrm{eV}$, while the slightly less stable hexagonal (wurtzite) structure has a direct band gap at about $3.67 \mathrm{eV}$ [17]. ZnS has been deposited by a number of different methods including thermal evaporation [18,19], metal-organic chemical vapor deposition [20], and pulsed electron deposition [21] as well as PLD [5,11,22,23].

$\mathrm{Cu}_{2} \mathrm{SnS}_{3}$ has previously been deposited as thin films by a variety of vacuum and non-vacuum methods including sulfurization of precursors produced by electron beam evaporation [16], sputtering [24], and electrodeposition [25] as well as, e.g., post-annealing of mixed elemental powders [26] and successive ionic layer absorption and reaction (SILAR) [27]. To our knowledge, $\mathrm{Cu}_{2} \mathrm{SnS}_{3}$ has not previously been deposited by PLD. Several different crystal structures have been proposed for $\mathrm{Cu}_{2} \mathrm{SnS}_{3}$

including cubic, tetragonal, and monoclinic phases with reported optical band gaps around $1 \mathrm{eV}$ and with some variation in reported values [16].

In the present work we examine the structural and optical properties as well as the stoichiometry of $\mathrm{ZnS}$ and $\mathrm{Cu}_{2} \mathrm{SnS}_{3}$ films deposited at different fluences and substrate temperatures. Knowledge of these phases may assist us in identifying some of the phases which may occur in films of $\mathrm{Cu}_{2} \mathrm{ZnSnS}_{4}$ deposited under similar conditions.

\section{Materials and methods}

\subsection{Pulsed laser deposition}

Pulsed laser ablation was carried out with a Nd:YAG laser operating at $355 \mathrm{~nm}$ with a pulse duration of $6 \mathrm{~ns}$ and a repetition rate of $10 \mathrm{~Hz}$. The target rotated as the laser rastered across an area of approx. 0.5 $\mathrm{cm}^{2}$ at an incident angle of $45^{\circ}$ with a spot size of $3 \mathrm{~mm}^{2}$ except for the measurements of the deposition rate at room temperature comparing $\mathrm{ZnS}$ to $\mathrm{Zn}, \mathrm{Cu}$, and $\mathrm{Sn}$, for which the spot size was $1 \mathrm{~mm}^{2}$. The 
substrates used in this study were fused silica. The target-substrate distance was kept constant at $45 \mathrm{~mm}$ and the substrate was clamped to a heated holder; the deposition temperature was monitored with a thermocouple mounted on the heater surface at the edge of the substrate. The base pressure of the deposition chamber was usually below $10^{-6}$ mbar.

Multicomponent hot-sintered targets were purchased from PVD products, Inc. The ZnS target was made at $1000^{\circ} \mathrm{C}$ from $\mathrm{ZnS}$ powder, while the target with $2 \mathrm{Cu}: \mathrm{Sn}: 3 \mathrm{~S}$ stoichiometry was made of a mixture of $\mathrm{Cu}_{2} \mathrm{~S}$ and $\mathrm{SnS}_{2}$ powder with 1:1 molar ratio at $750^{\circ} \mathrm{C}$. It is known that the detailed structure of the target does not play a significant role for the film composition except for cases where one or more components are very volatile.

The films of $\mathrm{ZnS}$ were deposited at room temperature to $300{ }^{\circ} \mathrm{C}$ at a laser fluence ranging from 0.8 to $1 \mathrm{~J} / \mathrm{cm}^{2}$ as well as at room temperature at a fluence of $1.4 \mathrm{~J} / \mathrm{cm}^{2}$. All the $\mathrm{ZnS}$ films were between 200 and $250 \mathrm{~nm}$ thick. The films of $\mathrm{Cu}_{2} \mathrm{SnS}_{3}$ were deposited at room temperature to $250{ }^{\circ} \mathrm{C}$ at a fluence of 0.4-0.6 J/cm ${ }^{2}$ as well as at room temperature and at $250^{\circ} \mathrm{C}$ at a fluence of $1.6 \mathrm{~J} / \mathrm{cm}^{2}$. The $\mathrm{Cu}_{2} \mathrm{SnS}_{3}$ films deposited were on average between 400 and $600 \mathrm{~nm}$ thick.

\subsection{Characterization}

Dektak profilometry was used to measure the thickness of deposited films of $\mathrm{Cu}_{2} \mathrm{SnS}_{3}$ and $\mathrm{ZnS}$. The thickness was converted to the number of atoms per pulse assuming a bulk density of $4.079 \mathrm{~g} / \mathrm{cm}^{2}$ for $\mathrm{ZnS}$ and $5.02 \mathrm{~g} / \mathrm{cm}^{2}$ for $\mathrm{Cu}_{2} \mathrm{SnS}_{3}$ [17].

The transmission of the films was measured with a Cary 50 photospectrometer and the absorption coefficient $\alpha$ estimated from the formula $\alpha=1 / \mathrm{d}^{*} \ln (1 / \mathrm{T})$, where $\mathrm{d}$ is the film thickness, and $\mathrm{T}$ the transmission as a fraction of 1 [28]. Here we make the simplifying assumption that all the incident light is either transmitted or absorbed, with reflection and scattering being negligible. The optical band gap was determined by extrapolating the quantity $(\alpha h v)^{2}$ to zero assuming direct optical transitions.

X-ray diffraction (XRD) was carried out using a Bruker D8 diffractometer in Bragg-Brentano configuration using $\mathrm{Cu} \mathrm{K} \alpha$ and $\mathrm{Cu} \mathrm{K}_{\beta}$ radiation. The step size was $0.02^{\circ}$ at $1 \mathrm{step} / \mathrm{s}$ for $\mathrm{ZnS}$ films $\left(0.01^{\circ}\right.$ steps at $0.75 \mathrm{step} / \mathrm{s}$ for the room temperature film shown in Fig. 3a) and $0.01^{\circ}$ using $0.75 \mathrm{step} / \mathrm{s}$ for the $\mathrm{Cu}_{2} \mathrm{SnS}_{3}$ films. Peaks were identified manually after stripping the $\mathrm{Cu} \mathrm{K}_{\alpha 2}$ signal using the program EVA and the peak patterns were matched to the relevant JCPDS files. 
Energy dispersive X-ray spectroscopy (EDX) was done with $15 \mathrm{keV}$ electrons with a Bruker Quantax 70 system integrated into a Hitachi TM3000 scanning electron microscope (X-ray take-off angle $25^{\circ}$ ). The average emission depth of the detected X-rays was modeled with CASINO software version 2.48 assuming a flat sample surface [29]. SEM imaging was carried out both with the Hitachi TM3000 microscope and with a Zeiss SUPRA SEM.

\section{Results and discussion}

The films of $\mathrm{ZnS}$ were transparent, appeared lightly colored due to thin film interference, and looked smooth (Fig 1a shows a $\mathrm{ZnS}$ film made at $200{ }^{\circ} \mathrm{C}$; films made at other temperatures looked very similar). The films of $\mathrm{Cu}_{2} \mathrm{SnS}_{3}$ (CTS) appeared gray and were rougher than the $\mathrm{ZnS}$ films as observed by scanning electron microscopy. From a rather unstructured appearance at room temperature, the $\mathrm{Cu}_{2} \mathrm{SnS}_{3}$ films changed to a granular structure at $150{ }^{\circ} \mathrm{C}$ and $250{ }^{\circ} \mathrm{C}$, as seen in Fig $1 \mathrm{~b}$-d. The SEM analysis revealed the presence of droplets on the surface of the $\mathrm{Cu}_{2} \mathrm{SnS}_{3}$ films with dimensions ranging from hundreds of nanometers up to one micron (Fig 1e shows a representative cross-section of the CTS film on fused $\mathrm{SiO}_{2}$ ).

\subsection{Deposition rate}

The deposition rate of $\mathrm{ZnS}$ and $\mathrm{Cu}_{2} \mathrm{SnS}_{3}$ was similar and did not change significantly with increasing deposition temperature from room temperature to $300{ }^{\circ} \mathrm{C}$ for $\mathrm{ZnS}$ and from room temperature to 250 ${ }^{\circ} \mathrm{C}$ for $\mathrm{Cu}_{2} \mathrm{SnS}_{3}$ (see Fig 2). This is consistent with the observations of Xin et al. [5], who found that the growth rate of $\mathrm{ZnS}$ was constant from room temperature to about $300^{\circ} \mathrm{C}$.

The deposition rate measurements of $\mathrm{Zn}, \mathrm{Cu}$ and $\mathrm{Sn}$ metals taken under similar conditions [30] is significantly lower than the deposition rate of $\mathrm{ZnS}$. This is partly because the heat conduction of sintered ZnS-target is much lower than for the metals and partly because the sintered target may have a high amount of defects at the grain boundaries which absorb photons at the laser energy $3.49 \mathrm{eV}$, which is slightly below the direct band gap energy of $3.54 \mathrm{eV}$ for a perfect cubic-phase $\mathrm{ZnS}$ crystal.

\subsection{Crystal structure}

Figure 3 shows $\mathrm{X}$-ray diffraction patterns for films of $\mathrm{ZnS}$ and $\mathrm{Cu}_{2} \mathrm{SnS}_{3}$ deposited at different temperatures. 
$\mathrm{ZnS}$ films deposited at room temperature show a broad X-ray diffraction peak at the expected position of the cubic (220)/hexagonal (110) reflection (Fig. 3a). As the deposition temperature increases, this peak disappears while reflections appear at about $28.5^{\circ}$, at a slightly smaller angle than the cubic (111) plane/hexagonal (002) plane, as well as at about 56 , at a slightly smaller angle than the cubic (311) plane/hexagonal (112) plane. Additionally, a small peak appears at about $26^{\circ}$ which may originate from the hexagonal (100) peak. The relatively high signal-to-noise ratio of the $\mathrm{ZnS} \mathrm{XRD}$ measurements occurs because the films are thin compared to the penetration depth of the X-rays. With increased temperature the main peak at $28.5^{\circ}$ increases in height, which could indicate an increasing fraction of crystalline versus amorphous material.

The observed peak positions are similar to observations using pulsed electron deposition by Zanettini et al. [21]. This group investigated the same range of deposition temperatures using soda lime glass substrates and observed a similar structural modification from preferential cubic (220) growth direction at room temperature to cubic (111)-growth at higher temperature. Unlike Zanettini et al., however, we do not clearly observe a complete transition to the hexagonal phase at $300{ }^{\circ} \mathrm{C}$. In another study using the same wavelength of the third harmonic of a pulsed Nd:YAG laser $(355 \mathrm{~nm})$ and a substrate temperature of $400{ }^{\circ} \mathrm{C}$, Yano et al. [23] find preferential cubic (111) and (311) direction growth similar to our results at elevated temperature. This group also found clear hexagonal-phase peaks at this relatively high growth temperature.

The X-ray diffraction patterns of the $\mathrm{Cu}_{2} \mathrm{SnS}_{3}$ films vary significantly more with deposition temperature than those of the $\mathrm{ZnS}$ films, as seen in Fig. 3b. The films deposited at room temperature appear amorphous. In contrast, the XRD pattern from one of the $\mathrm{Cu}_{2} \mathrm{SnS}_{3}$ films made at a substrate temperature of $150{ }^{\circ} \mathrm{C}$ clearly indicates tetragonal $\mathrm{Cu}_{2} \mathrm{SnS}_{3}$ with preferential growth in the (112) and (220) directions (expected peaks from the (200) and (312) planes are not visible). At $250{ }^{\circ} \mathrm{C}$ the diffraction peaks consistently match a mix of cubic-phase $\mathrm{Cu}_{2} \mathrm{SnS}_{3}$ with other phases, including clear

peaks belonging to $\mathrm{Cu}_{4} \mathrm{SnS}_{4}$ (orthorhombic) and $\mathrm{SnS}$ (orthorhombic). See Table 1 (all JCPDS references in the caption of Fig. 3).

\subsection{Elemental composition}

Results from energy dispersive X-ray spectroscopy (EDX) show that the expected elements are present in the films ( $\mathrm{Zn}$ and $\mathrm{S}$ for $\mathrm{ZnS} ; \mathrm{Cu}, \mathrm{Sn}$ and $\mathrm{S}$ for $\mathrm{Cu}_{2} \mathrm{SnS}_{3}$ ). Quantifying the amount of each element is 
difficult as the $15 \mathrm{keV}$ electrons penetrate the layer of interest and enter partly into the substrate, such that the X-ray signal does not derive from a uniform region (see Table 1). This geometry most likely causes overestimation of the signal of $\mathrm{Zn}$ in $\mathrm{ZnS}$ and of $\mathrm{Cu}$ in $\mathrm{Cu}_{2} \mathrm{SnS}_{3}$. Nonetheless, films of similar thickness may be compared.

On this basis, we can show that for the $\mathrm{ZnS}$ films there is less $\mathrm{S}$ in films deposited at room temperature than at elevated temperature, while there is no difference between the composition of films deposited at $100{ }^{\circ} \mathrm{C}, 200{ }^{\circ} \mathrm{C}$, and $300{ }^{\circ} \mathrm{C}$ within $+/-1$ at. $\%$ equivalent to the variation between measurements of the same film. Changing the fluence from $0.8 \mathrm{~J} / \mathrm{cm}^{2}$ to $1.4 \mathrm{~J} / \mathrm{cm}^{2}$ does not measurably alter the composition of films at room temperature.

Similarly, for the $\mathrm{Cu}_{2} \mathrm{SnS}_{3}$ films, the S-content increases as the deposition temperature is raised from room temperature to $250{ }^{\circ} \mathrm{C}$. Moreover, an increase in fluence from $0.6 \mathrm{~J} / \mathrm{cm}^{2}$ to $1.6 \mathrm{~J} / \mathrm{cm}^{2}$ results in a decrease in $\mathrm{S}$ and $\mathrm{Sn}$ content (Table 1). The S:Sn ratio is lower than three for all fluences, indicating S loss at all fluences since the Sn L-lines and S K-lines have a similar emission profile over the sample depth as modeled by Casino. The appearance of $\mathrm{Cu}_{4} \mathrm{SnS}_{4}$ and $\mathrm{SnS}$ together with $\mathrm{Cu}_{2} \mathrm{SnS}_{3}$ in all films made at $250{ }^{\circ} \mathrm{C}$ may be an effect of the $\mathrm{S}$ loss, as these compounds are S-deficient relative to $\mathrm{Cu}_{2} \mathrm{SnS}_{3}$. It is worth noting that even at high fluence at $250{ }^{\circ} \mathrm{C}$, where the films contain least $\mathrm{Sn}$ and $\mathrm{S}, \mathrm{SnS}$ is detected by X-ray diffraction alongside $\mathrm{Cu}_{2} \mathrm{SnS}_{3}$ and $\mathrm{Cu}_{4} \mathrm{SnS}_{4}$. However the peaks for $\mathrm{Cu}_{4} \mathrm{SnS}_{4}$ are relatively more pronounced and the $\mathrm{SnS}$ peaks smaller at high fluence than low fluence, matching the lower Sn content (not shown).

\subsection{Optical properties}

The absorption properties of the $\mathrm{ZnS}$ thin films as a function of deposition temperature are shown in Fig. 4a. The optical band gap of $\mathrm{ZnS}$ increases with the deposition temperature in a manner very similar to that observed by Zanettini et al. [21] using pulsed electron deposition (inset in Fig. 4a). The trend of increasing optical band gap with increasing temperature was also seen for laser-deposited films at temperatures from room temperature to $660{ }^{\circ} \mathrm{C}$ by Xin et al. [5], although this group did not see an optical band gap at all for films deposited at room temperature.

As estimated from Fig. 4a, the value for the optical band gap of the film deposited at $300{ }^{\circ} \mathrm{C}$ approaches the expected value of the direct band gap of cubic $\mathrm{ZnS}$, i.e, $3.54 \mathrm{eV}$. Together with the 
XRD data, which show an increase in crystallite formation with deposition temperature, the increase in optical band gap with temperature may reflect a change from a material that is partly amorphous with small cubic-phase crystallites to a material with larger crystals and a mix of cubic-phase and hexagonal-phase crystals, increasing the average absorption threshold.

On close comparison to the data of Zanettini et al. [21], it is interesting to note that the highest optical band gap observed by Zanettini et al. is slightly higher than that observed here, and is closer to the direct electronic band gap of hexagonal-phase $\mathrm{ZnS}$, which is $3.67 \mathrm{eV}$. This may reflect a difference between pulsed laser and pulsed electron deposition, with a clearer transition to the hexagonal phase already at $300{ }^{\circ} \mathrm{C}$ with pulsed electron deposition. This would parallel the observed difference in the $\mathrm{X}$ ray diffraction patterns, where Zanettini et al. observe a change to a pattern that more closely matches the hexagonal phase at $300{ }^{\circ} \mathrm{C}$.

The transmission spectrum of the $\mathrm{Cu}_{2} \mathrm{SnS}_{3}$ thin films deposited at different temperatures is shown in Fig. $4 \mathrm{~b}$. It is clear that the threshold of transmission increases with temperature and the data indicate that the optical band gap of the $\mathrm{Cu}_{2} \mathrm{SnS}_{3}$ films decreases with increasing deposition temperature from about $1.55 \mathrm{eV}$ to $1.35 \mathrm{eV}$. The peak or shoulder at about $1.5 \mathrm{eV}$ is possibly due to thin film interference. As the temperature increases, the value of the energy gap approaches those found in literature for cubic-phase $\mathrm{Cu}_{2} \mathrm{SnS}_{3}$ of about $1 \mathrm{eV}$. However, as noted earlier, the literature values for the optical band gap vary widely. The measured band gap of $\sim 1.45 \mathrm{eV}$ for the $150{ }^{\circ} \mathrm{C}$ film, which appears from its XRD pattern to be tetragonal-phase $\mathrm{Cu}_{2} \mathrm{SnS}_{3}$, is not far from the previously reported band gap of $1.35 \mathrm{eV}$ for this phase [31]. The XRD patterns of the $250{ }^{\circ} \mathrm{C}$ films indicate that we do not have pure phase $\mathrm{Cu}_{2} \mathrm{SnS}_{3}$ at this temperature but rather a mix of phases and the optical band gap must therefore reflect a mix of the absorption of these different phases.

\section{Conclusion}

In this work we have shown that pulsed laser deposition of $\mathrm{ZnS}$ can result in a high deposition rate, with films most likely consisting of a mix of cubic and hexagonal phases. The film quality appears to improve with substrate temperature up to $300{ }^{\circ} \mathrm{C}$ : with increasing temperature the optical band gap approaches that of the direct band gap of cubic-phase $\mathrm{ZnS}$ while the X-ray diffraction pattern indicates 
an increasing crystalline fraction. These results are in close agreement with results from both pulsed laser deposition and pulsed electron deposition [5,21,23].

We have successfully used pulsed laser deposition to create films of $\mathrm{Cu}_{2} \mathrm{SnS}_{3}$ in the tetragonal phase at $150{ }^{\circ} \mathrm{C}$, though more work is needed to confirm that the films are stoichiometric. These films are covered by particulates, but this issue can, for example, be reduced by applying a shorter wavelength, e.g. $248 \mathrm{~nm}$, in the PLD-process [3]. At $250{ }^{\circ} \mathrm{C}$ the X-ray diffraction patterns indicate that $\mathrm{Cu}_{4} \mathrm{SnS}_{4}$ and $\mathrm{SnS}$ form in addition to cubic-phase $\mathrm{Cu}_{2} \mathrm{SnS}_{3}$. Energy dispersive X-ray spectroscopy shows that $\mathrm{S}$ and Sn content declines in the $\mathrm{Cu}_{2} \mathrm{SnS}_{3}$ films with increasing fluence. Further studies will cast more light on the secondary phases that may be formed within the range of conditions used to deposit the solar cell absorber material $\mathrm{Cu}_{2} \mathrm{ZnSnS}_{4}$. However, a complete analysis of the temperature dependence of the phase growth is not straightforward because of the many possible phases during film growth, which also may be promoted by the high kinetic energy of the arriving particles.

\section{Acknowledgments}

This work has been supported by a grant from the Danish Council for Strategic Research. The authors thank Jørgen Stubager for competent technical assistance. 


\section{Figure captions}

Figure 1: SEM images of as-deposited films: a) $\mathrm{ZnS}$ deposited at $200^{\circ} \mathrm{C}$ at a fluence of $0.9 \mathrm{~J} / \mathrm{cm}^{2}$; b) $\mathrm{Cu}_{2} \mathrm{SnS}_{3}$ film deposited at $20^{\circ} \mathrm{C}$, fluence $1.4 \mathrm{~J} / \mathrm{cm}^{2}$, XRD pattern: amorphous; c) $\mathrm{Cu}_{2} \mathrm{SnS}_{3}$ film deposited at $150^{\circ} \mathrm{C}$, fluence $0.5 \mathrm{~J} / \mathrm{cm}^{2}$, XRD pattern: $\mathrm{Cu}_{2} \mathrm{SnS}_{3}$ (tetragonal); d) $\mathrm{Cu}_{2} \mathrm{SnS}_{3}$ film deposited at $250^{\circ} \mathrm{C}$, fluence $0.4 \mathrm{~J} / \mathrm{cm}^{2}, \mathrm{XRD}$ pattern: $\mathrm{Cu}_{2} \mathrm{SnS}_{3}$ (cubic), $\mathrm{Cu}_{4} \mathrm{SnS}_{4}$ (orth), $\mathrm{SnS}$ (orth). e) Cross section of film shown in (d). Note different scales on images.

Figure 2: Deposition rate of $\mathrm{ZnS}$ and $\mathrm{Cu}_{2} \mathrm{SnS}_{3}$ ablated with a $3 \mathrm{~mm}^{2}$ spot size onto room temperature or heated substrates of fused silica or silicon. Deposition rate error derives from variation in thickness at different locations on the films. Fluence error derives from variation in laser energy and vacuum chamber window transmission during the deposition.

Figure 3: X-ray diffraction patterns for a) $\mathrm{ZnS}$ thin films and b) $\mathrm{Cu}_{2} \mathrm{SnS}_{3}$ thin films. $\mathrm{K}_{\alpha 2}$ signal has been removed. The $\mathrm{ZnS}$ films were made with a fluence of $0.8-1 \mathrm{~J} / \mathrm{cm}^{2}$ while the $\mathrm{Cu}_{2} \mathrm{SnS}_{3}$ were made with a fluence of 0.5-0.6 J/ $\mathrm{cm}^{2}$. The stars in (b) denote peaks of orthorhombic SnS (JCPDS 75-2115) Hexagonal ZnS: JCPDS 36-1450; cubic ZnS: JCPDS 05-0566; tetragonal $\mathrm{Cu}_{2} \mathrm{SnS}_{3}$ : JCPDS 89-2877; cubic $\mathrm{Cu}_{2} \mathrm{SnS}_{3}$ : JCPDS 89-4714; orthorhombic $\mathrm{Cu}_{4} \mathrm{SnS}_{4}$ : JCPDS 71-0129.

Figure 4: a) Optical band gap of $\mathrm{ZnS}$. For $\mathrm{ZnS}$ the optical band gap estimate is $~ 3.15 \mathrm{eV}, 3.3 \mathrm{eV}, 3.5$ $\mathrm{eV}$, and $3.55 \mathrm{eV}$ for films deposited at $20{ }^{\circ} \mathrm{C}, 100{ }^{\circ} \mathrm{C}, 200{ }^{\circ} \mathrm{C}$, and $300{ }^{\circ} \mathrm{C}$. The box inset in (a) shows the absorption threshold measured by Zanettini et al. [21] for films made by pulsed electron deposition, reproduced by permission of the authors. b) Transmission spectrum of $\mathrm{Cu}_{2} \mathrm{SnS}_{3}$ for films deposited at $20^{\circ} \mathrm{C}, 150{ }^{\circ} \mathrm{C}$, and $250{ }^{\circ} \mathrm{C}$. 


\section{Table 1}

\section{EDX and X-ray diffraction data for films made from the $\mathrm{ZnS}$ target}

\begin{tabular}{|c|c|c|c|c|c|c|}
\hline & $\begin{array}{l}\text { Fluence } \\
\left(\mathrm{J} / \mathrm{cm}^{2}\right)\end{array}$ & $\begin{array}{l}\text { Thickness } \\
(\mathrm{nm})^{*}\end{array}$ & $\begin{array}{l}\text { Mean EDX } \\
\text { emission } \\
\text { depth }(\mathrm{nm}) * *\end{array}$ & $\begin{array}{l}\mathrm{Zn} \\
(\%)^{* * *}\end{array}$ & $\begin{array}{l}\mathrm{S} \\
(\%)\end{array}$ & X-ray pattern matches \\
\hline RT & 0.8 & 230 & 600 & 60 & 40 & $\mathrm{ZnS}$ cubic $(220)$ \\
\hline 100 & 0.8 & 250 & 600 & 57 & 43 & $\begin{array}{l}\text { ZnS cubic (111), hex } \\
(100)\end{array}$ \\
\hline 200 & 0.9 & 200 & 600 & 56 & 44 & 66 \\
\hline 300 & 1.0 & 250 & 600 & 57 & 43 & 6 \\
\hline \multicolumn{3}{|c|}{ Target, unablated } & - & 53 & 47 & - \\
\hline
\end{tabular}

EDX and X-ray diffraction data for $\mathrm{Cu}-\mathrm{Sn}-\mathrm{S}$ films made from the $\mathrm{Cu}_{2} \mathrm{SnS}_{3}$ target

\begin{tabular}{|c|c|c|c|c|c|c|c|}
\hline & $\begin{array}{l}\text { Fluence } \\
\left(\mathrm{J} / \mathrm{cm}^{2}\right)\end{array}$ & $\begin{array}{l}\text { Thickness } \\
(\mathrm{nm})^{*}\end{array}$ & $\begin{array}{l}\text { Mean EDX } \\
\text { emission } \\
\text { depth }(\mathrm{nm}) * *\end{array}$ & $\begin{array}{l}\mathrm{Cu} \\
(\%)^{* * *}\end{array}$ & $\begin{array}{l}\mathrm{Sn} \\
(\%)\end{array}$ & $\begin{array}{l}\text { S } \\
(\%)\end{array}$ & X-ray pattern matches \\
\hline $\mathrm{RT}$ & 0.6 & 400 & 250 & 43 & 19 & 38 & Amorphous \\
\hline ، & 1.6 & 400 & 250 & 52 & 15 & 33 & “6 \\
\hline 150 & 0.5 & 500 & 250 & 40 & 18 & 42 & $\mathrm{Cu}_{2} \mathrm{SnS}_{3}$ tetragonal \\
\hline 250 & 0.6 & 500 & 250 & 41 & 17 & 42 & $\begin{array}{l}\mathrm{Cu}_{2} \mathrm{SnS}_{3} \text { cubic, } \\
\mathrm{Cu}_{2} \mathrm{SnS}_{4} \text { orth, } \mathrm{SnS} \text { orth }\end{array}$ \\
\hline 6 & 1.6 & 400 & 250 & 46 & 16 & 38 & “ \\
\hline \multicolumn{3}{|c|}{ Target, unablated } & - & 36 & 19 & 43 & - \\
\hline
\end{tabular}

* Thickness of $\mathrm{ZnS}$ films averaged to nearest $10 \mathrm{~nm}$; thickness of $\mathrm{Cu}_{2} \mathrm{SnS}_{3}$ films averaged nearest 100 $\mathrm{nm}$ (due to droplets on $\mathrm{Cu}-\mathrm{Sn}-\mathrm{S}$ film surfaces, some parts of these films are thicker).

** $50 \%$ of the X-rays reaching the EDX detector come from this depth or less; emissions are averaged from $\mathrm{Zn}$ and $\mathrm{S}$ K-lines or, as appropriate, from $\mathrm{Cu}$ K-lines, Sn L-lines and S K-lines (15 keV electron excitation modeled by Casino [29]).

*** $\mathrm{Zn}$ and $\mathrm{Cu} \mathrm{K}$-lines are used. $\mathrm{Cu}$ and $\mathrm{Zn}$ are overestimated in films thinner than the penetration depth of the electrons. The variation in measurements made on different films made under the same circumstances and on the same film measured on different days is approx. 1-2\% absolute. 


\section{References}

[1] R.W. Eason, ed., Pulsed Laser Deposition of Thin Films, Wiley, Hoboken, NJ, 2007.

[2] J. Schou, Physical aspects of the pulsed laser deposition technique: The stoichiometric transfer of material from target to film, Appl. Surf. Sci. 255 (2009) 5191-5198.

[3] D.H. Lowndes, Laser ablation and desorption, in: J.C. Miller, R.F. Haglund (Eds.), Exp. Methods Phys. Sci. Vol 30, Academic Press, New York, 1998: pp. 475-571.

[4] C. Karner, P. Maguire, M. McLaughlin, S. Laverty, W.G. Graham, T. Morrow, et al., Pulsedlaser deposition of ZnS and SrS for ACTFEL and field-emission displays, in: Second Int. Conf. Sci. Technol. Disp. Phosphors, 1996.

[5] Z.-J. Xin, R.J. Peaty, H.N. Rutt, R.W. Eason, Epitaxial growth of high-quality ZnS films on sapphire and silicon by pulsed laser deposition, Semicond. Sci. Technol. 14 (1999) 695-698.

[6] J. Lanèok, M. Jelí, L. Jastrabí, L. Soukup, J. Oswald, K. Jurek, et al., Laser deposition of waveguiding Ti : sapphire and chalcogenide glass AsS films, in: Superf. Y Vacio, 1999: pp. 316-319.

[7] H. Ogura, K. Matsuishi, S. Onari, Raman scattering and photodarkening of amorphous Ge(1$\mathrm{X}) \mathrm{S}(\mathrm{X})(0<\mathrm{X}<0.62)$ films, J. Non-Cryst. Solids. 270 (2000) 147-153.

[8] S. Canulescu, T. Lippert, A. Wokaun, R. Robert, D. Logvinovich, A. Weidenkaff, et al., Preparation of epitaxial La0.6Ca0.4Mn1-xFexO3 $(x=0,0.2)$ thin films: Variation of the oxygen content, Prog. Solid State Chem. 35 (2007) 241-248.

[9] B. Thestrup, J. Schou, A. Nordskov, N.B. Larsen, Electrical and optical properties of thin indium tin oxide films produced by pulsed laser ablation in oxygen or rare gas atmospheres, Appl. Surf. Sci. 142 (1999) 248-252.

[10] H. Hiramatsu, H. Ohta, M. Hirano, H. Hosono, Heteroepitaxial growth of single-phase zinc blende $\mathrm{ZnS}$ films on transparent substrates by pulsed laser deposition under $\mathrm{H}_{2} \mathrm{~S}$ atmosphere, Solid State Commun. 124 (2002) 411-415.

[11] M. McLaughlin, H.F. Sakeek, P. Maguire, W.G. Graham, J. Molloy, T. Morrow, et al., Properties of $\mathrm{ZnS}$ thin films prepared by 248-nm pulsed laser deposition, Appl. Phys. Lett. 63 (1993) 1865.

[12] A. Cazzaniga, A. Crovetto, S. Canulescu, J. Schou, N. Pryds, O. Hansen, Thin films of CZTS for solar cells prepared by pulsed laser deposition, submitted to Appl. Phys. B. 
[13] B. Shin, O. Gunawan, Y. Zhu, N.A. Bojarczuk, S.J. Chey, S. Guha, Thin film solar cell with 8.4 $\%$ power conversion efficiency using an earth-abundant $\mathrm{Cu} 2 \mathrm{ZnSnS} 4$ absorber, Prog. Photovoltaics Res. Appl. 21 (2013) 72-76.

[14] S. Siebentritt, Why are kesterite solar cells not 20\% efficient?, Thin Solid Films. 535 (2013) 1-4.

[15] P.J. Dale, K. Hoenes, J.J. Scragg, S. Siebentritt, A review of the challenges facing kesterite based thin film solar cells, 2009 34th IEEE Photovolt. Spec. Conf. (2009) 002080-002085.

[16] N. Aihara, H. Araki, A. Takeuchi, K. Jimbo, H. Katagiri, Fabrication of $\mathrm{Cu}_{2} \mathrm{SnS}_{3}$ thin films by sulfurization of evaporated Cu-Sn precursors for solar cells, Phys. Status Solidi. 10 (2013) 10861092.

[17] L.I. Berger, Properties of Semiconductors, in: W.M. Haynes (Ed.), Handb. Chem. Phys., 95th ed., Taylor and Francis Group, LLT, 2014: pp. 80-85.

[18] J.T. Cox, G. Hass, Optical Properties of Zinc Sulfide in the Vacuum Ultraviolet, J. Opt. Soc. Am. 49 (1959) 807-810.

[19] X. Wu, F. Lai, L. Lin, J. Lv, B. Zhuang, Q. Yan, et al., Optical inhomogeneity of ZnS films deposited by thermal evaporation, Appl. Surf. Sci. 254 (2008) 6455-6460.

[20] A. Abounadi, M. Di Blasio, D. Bouchara, J. Calas, M. Averous, O. Briot, et al., Reflectivity and photoluminescence measurements in $\mathrm{ZnS}$ epilayers grown by metal-organic chemical-vapor deposition, Phys. Rev. B. 50 (1994).

[21] S. Zanettini, F. Bissoli, L. Nasi, P. Ranzieri, E. Gilioli, Low temperature pulsed electron deposition and characterization of $\mathrm{ZnS}$ films for application in solar cells, Cryst. Res. Technol. 46 (2011) 881-884.

[22] J.W. McCamy, D.H. Lowndes, J.D. Budai, R. A. Zuhr, X. Zhang, Epitaxial ZnS films grown on GaAs (001) and (111) by pulsed-laser ablation, J. Appl. Phys. 73 (1993) 7818.

[23] S. Yano, R. Schroeder, H. Sakai, B. Ullrich, Absorption and photocurrent properties of thin ZnS films formed by pulsed-laser deposition on quartz, Thin Solid Films 423 (2003) 273-276.

[24] H. Zhang, M. Xie, S. Zhang, Y. Xiang, Fabrication of highly crystallized $\mathrm{Cu}_{2} \mathrm{SnS}_{3}$ thin films through sulfurization of Sn-rich metallic precursors, J. Alloys Compd. 602 (2014) 199-203.

[25] D.M. Berg, R. Djemour, L. Gütay, S. Siebentritt, P.J. Dale, X. Fontane, et al., Raman analysis of monoclinic $\mathrm{Cu}_{2} \mathrm{SnS}_{3}$ thin films, Appl. Phys. Lett. 100 (2012) 192103.

[26] T. Nomura, T. Maeda, T. Wada, Preparation of Narrow Band-Gap $\mathrm{Cu}_{2} \mathrm{Sn}(\mathrm{S}, \mathrm{Se})_{3}$ and Fabrication of Film by Non-Vacuum Process, Jpn. J. Appl. Phys. 52 (2013) 04CR08. 
[27] H. Guan, H. Shen, C. Gao, X. He, Structural and optical properties of $\mathrm{Cu}_{2} \mathrm{SnS}_{3}$ and $\mathrm{CuSnS}_{4}$ thin films by successive ionic layer adsorption and reaction, J. Mater. Sci.: Mater. Electron 24 (2013) 1490-1494.

[28] M. Fox, Introduction, in: Opt. Prop. Solids, Oxford University Press, 2001: p. 3.

[29] D. Drouin, A.R. Couture, D. Joly, X. Tastet, V. Aimez, R. Gauvin, CASINO V2.42: a fast and easy-to-use modeling tool for scanning electron microscopy and microanalysis users., Scanning. 29 (2007) 92-101.

[30] A. Cazzaniga, R.B. Ettlinger, S. Canulescu, J. Schou, N. Pryds, Nanosecond laser ablation and deposition of silver, copper, zinc and tin, Appl. Phys. A. 87 (2014) 89-92.

[31] P. A. Fernandes, P.M.P. Salomé, A.F. da Cunha, A study of ternary $\mathrm{Cu}_{2} \mathrm{SnS}_{3}$ and $\mathrm{Cu}_{3} \mathrm{SnS}_{4}$ thin films prepared by sulfurizing stacked metal precursors, J. Phys. D. Appl. Phys. 43 (2010) 215403. 
a)

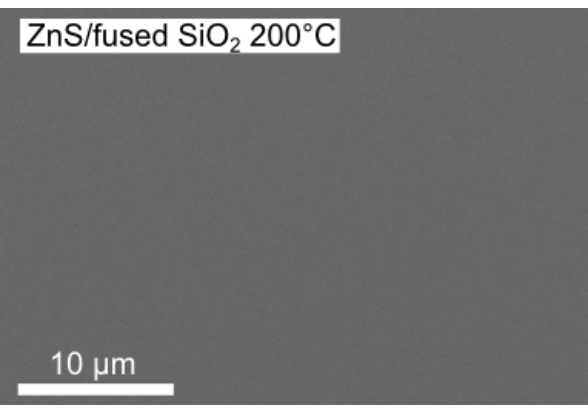

b)

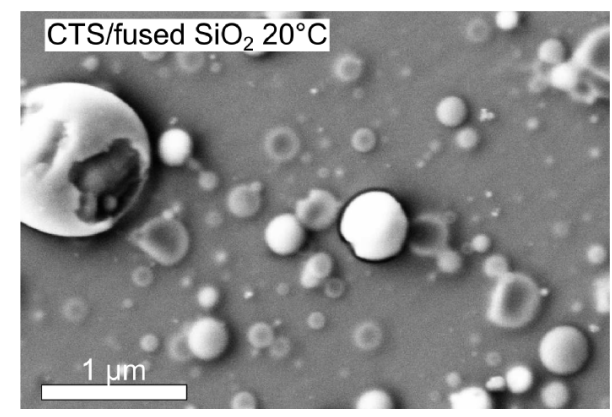

c)

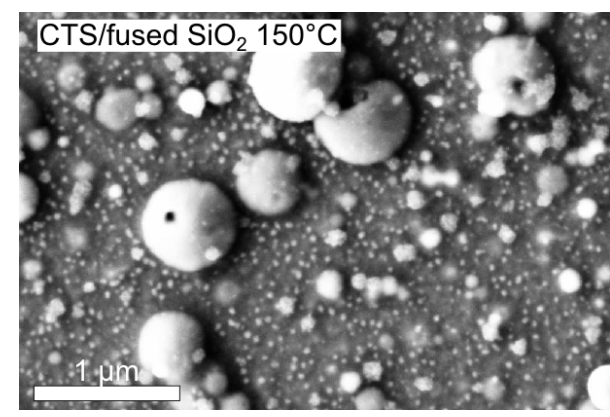

d)

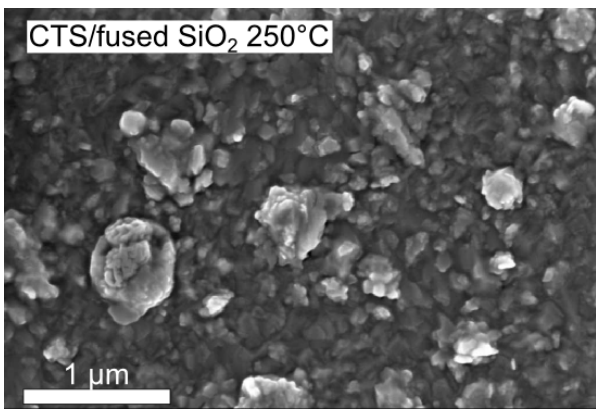

e)

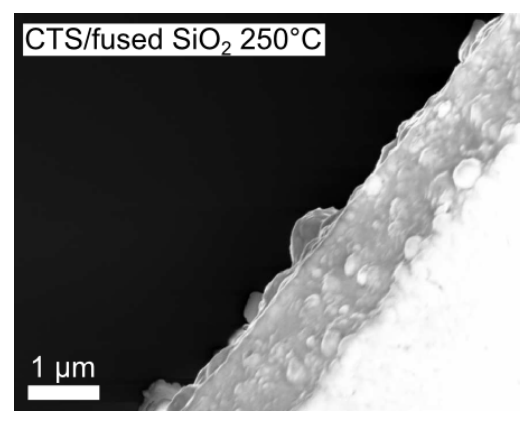

Figure 1: SEM images of as-deposited films: a) $\mathrm{ZnS}$ deposited at $200^{\circ} \mathrm{C}$ at a fluence of 0.9 $\mathrm{J} / \mathrm{cm}^{2}$; b) $\mathrm{Cu}_{2} \mathrm{SnS}_{3}$ film deposited at $20^{\circ} \mathrm{C}$, fluence $1.4 \mathrm{~J} / \mathrm{cm}^{2}$, XRD pattern: amorphous; c) $\mathrm{Cu}_{2} \mathrm{SnS}_{3}$ film deposited at $150^{\circ} \mathrm{C}$, fluence 0.5 $\mathrm{J} / \mathrm{cm}^{2}$, XRD pattern: $\mathrm{Cu}_{2} \mathrm{SnS}_{3}$ (tetragonal); d) $\mathrm{Cu}_{2} \mathrm{SnS}_{3}$ film deposited at $250^{\circ} \mathrm{C}$, fluence 0.4 $\mathrm{J} / \mathrm{cm}^{2}$, XRD pattern: $\mathrm{Cu}_{2} \mathrm{SnS}_{3}$ (cubic), $\mathrm{Cu}_{4} \mathrm{SnS}_{4}$ (orth), SnS (orth). e) Cross section of film shown in (d). Note different scales on images. 


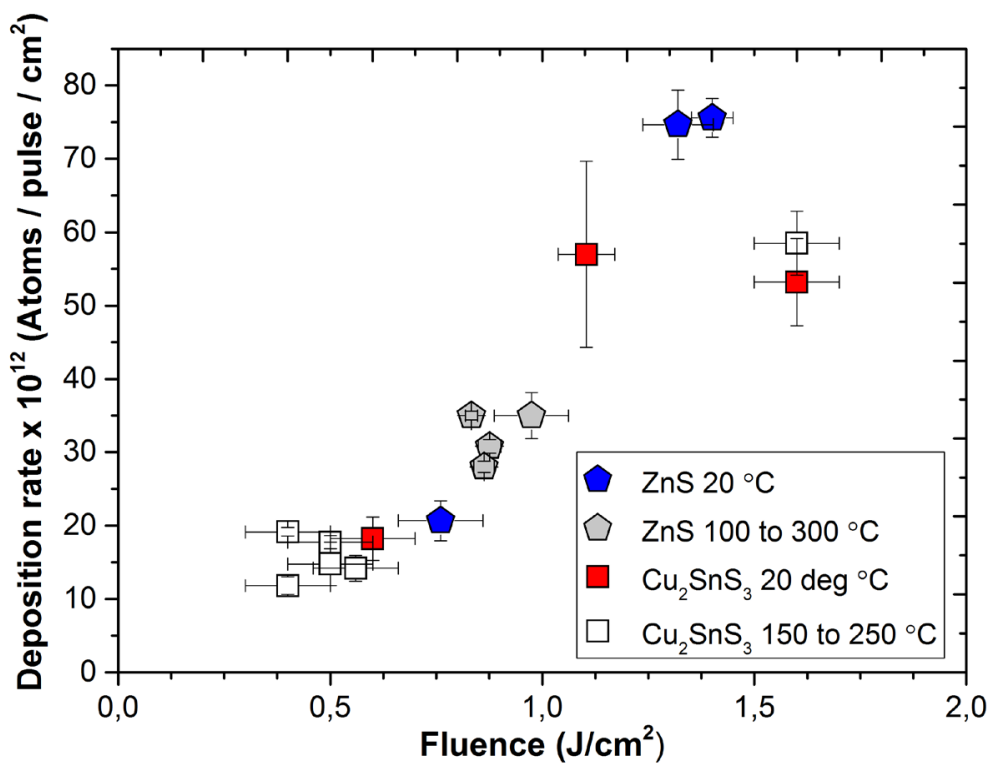

Figure 2: Deposition rate of $\mathrm{ZnS}$ and $\mathrm{Cu}_{2} \mathrm{SnS}_{3}$ ablated with a $3 \mathrm{~mm}^{2}$ spot size onto room temperature or heated substrates of fused silica or silicon. Deposition rate error in derives from variation in thickness at different locations on the films. Fluence error derives from variation in laser energy and vacuum chamber window transmission during the deposition. 

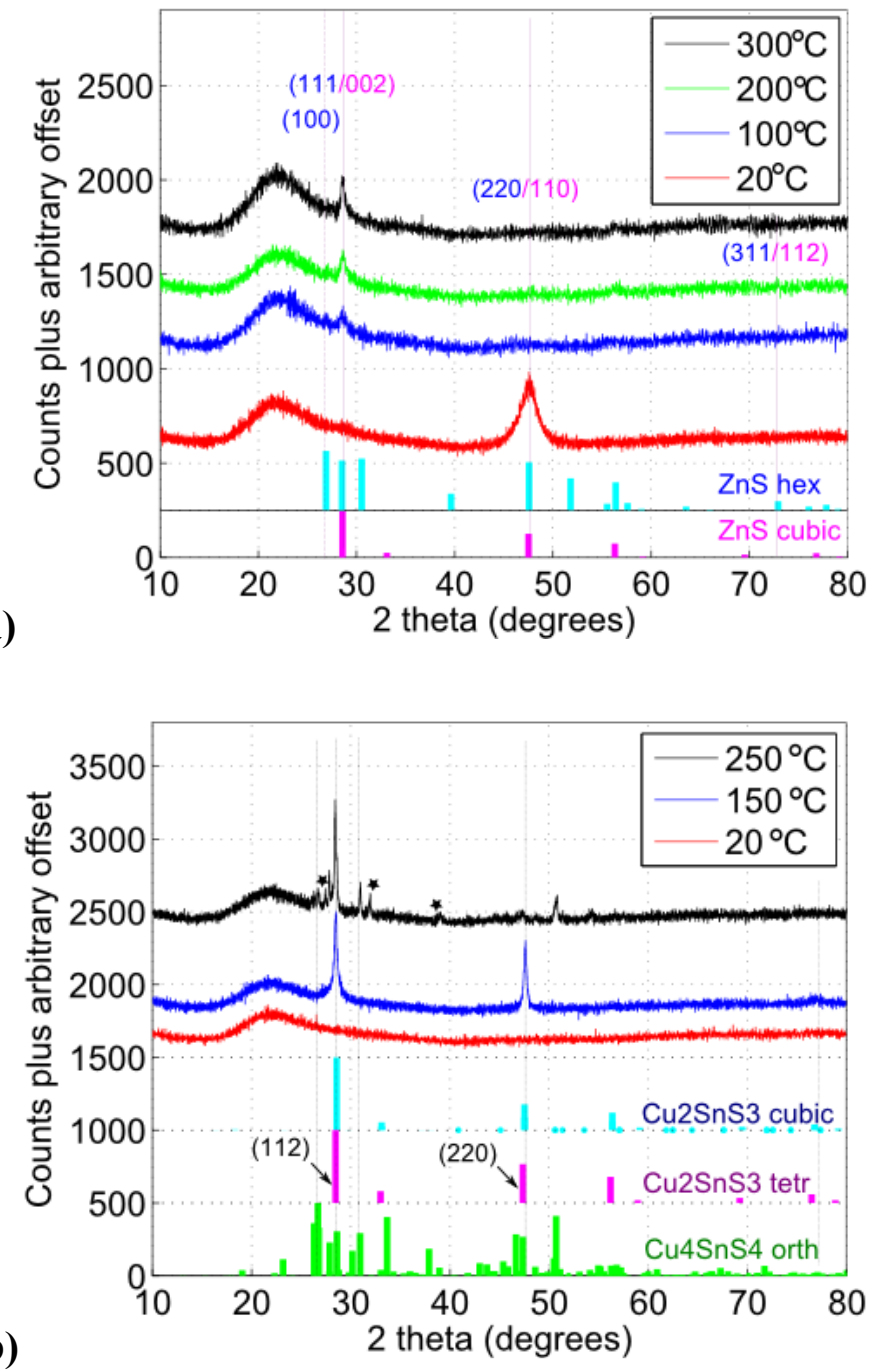

Figure 3: X-ray diffraction patterns for a) $\mathrm{ZnS}$ thin films and b) $\mathrm{Cu}_{2} \mathrm{SnS}_{3}$ thin films. $\mathrm{K}_{\alpha 2}$ signal has been removed. The $\mathrm{ZnS}$ films were made with a fluence of $0.8-1 \mathrm{~J} / \mathrm{cm}^{2}$ while the $\mathrm{Cu}_{2} \mathrm{SnS}_{3}$ were made with a fluence of 0.5-0.6 J/ $\mathrm{cm}^{2}$. The stars in (b) denote peaks of orthorhombic SnS (JCPDS 75-2115) Hexagonal ZnS: JCPDS 36-1450; cubic ZnS: JCPDS 05-0566; tetragonal $\mathrm{Cu}_{2} \mathrm{SnS}_{3}$ : JCPDS 89-2877; cubic $\mathrm{Cu}_{2} \mathrm{SnS}_{3}$ : JCPDS 89-4714; orthorhombic $\mathrm{Cu}_{4} \mathrm{SnS}_{4}$ : JCPDS 71-0129. 


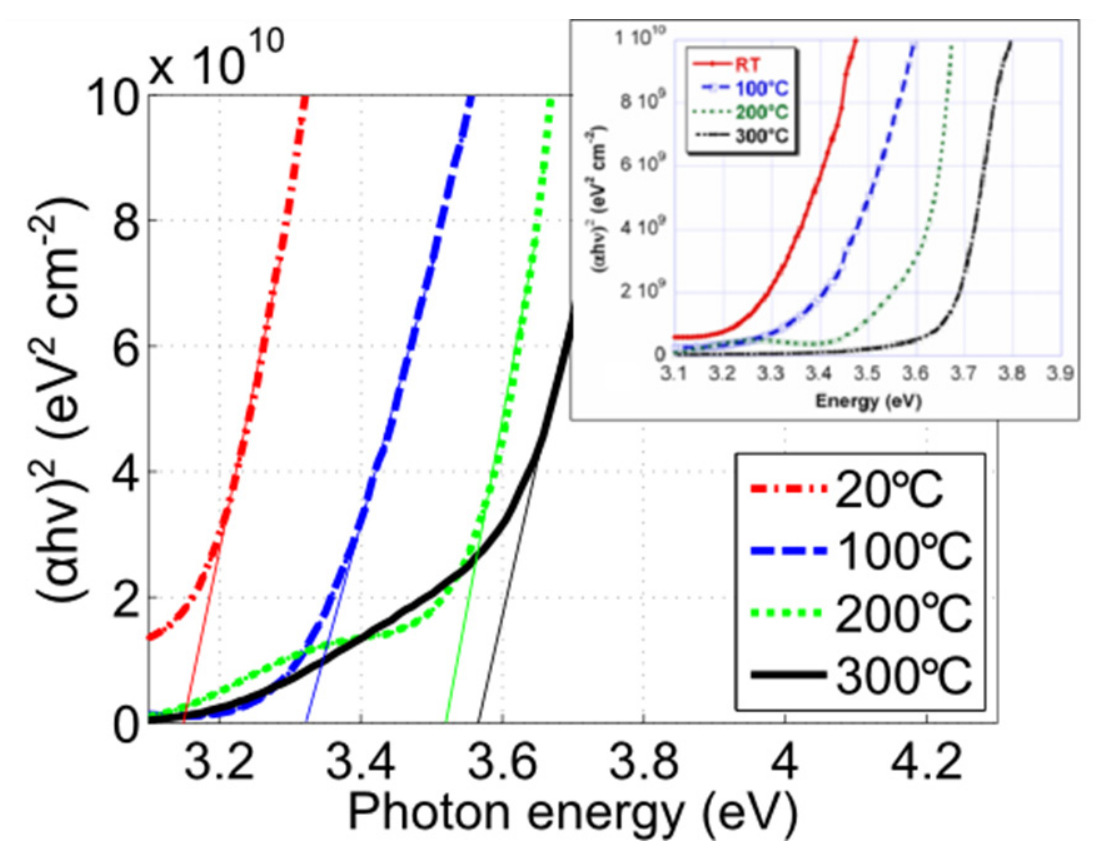

a)

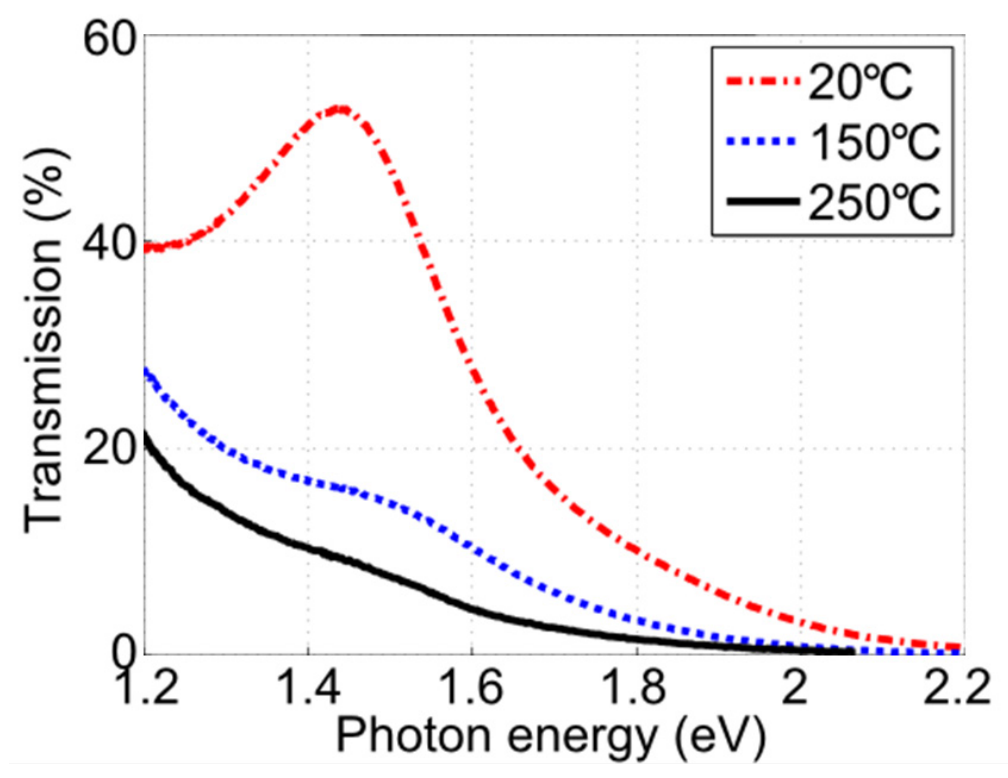

b)

Figure 4: a) Optical band gap of $\mathrm{ZnS}$. For $\mathrm{ZnS}$ the optical band gap estimate is $~ 3.15 \mathrm{eV}, 3.3 \mathrm{eV}, 3.5$ $\mathrm{eV}$, and $3.55 \mathrm{eV}$ for films deposited at $20{ }^{\circ} \mathrm{C}, 100{ }^{\circ} \mathrm{C}, 200{ }^{\circ} \mathrm{C}$, and $300{ }^{\circ} \mathrm{C}$. The box inset in (a) shows the absorption threshold measured by Zanettini et al. [21] for films made by pulsed electron deposition, reproduced by permission of the authors. b) Transmission spectrum of $\mathrm{Cu}_{2} \mathrm{SnS}_{3}$ for films deposited at $20{ }^{\circ} \mathrm{C}, 150{ }^{\circ} \mathrm{C}$, and $250{ }^{\circ} \mathrm{C}$. 